Arq. Bras. Med. Vet. Zootec., v.69, n.6, p.1508-1512, 2017

\title{
Evaluation of adjuvant chemotherapy in feline injection site-associated sarcoma
}

\author{
[Avaliação da quimioterapia no tratamento do sarcoma de aplicação felino] \\ S.T. Pereira ${ }^{1}$, C.B. Campos ${ }^{2,3}$, R.S. Horta ${ }^{1}$, G.E. Lavalle ${ }^{1}$, R.B. Araujo ${ }^{1}$ \\ ${ }^{1}$ Escola de Veterinária - Universidade Federal de Minas Gerais - EV-UFMG - Belo Horizonte, MG \\ ${ }^{2}$ Aluno de pós-graduação - FCAV/UNESP-Jaboticabal - Jaboticabal, SP \\ ${ }^{3}$ Instituto de Ciências Biológicas - Universidade Federal de Minas Gerais - ICB-UFMG - Belo Horizonte, MG
}

\begin{abstract}
Feline Injection Site-Associated Sarcoma (FISS) is a neoplasm that implies in reduction of quality of life and overall survival in feline patients. A retrospective study of 13 cases of FISS was conducted to evaluate the efficacy of surgical treatment associated to chemotherapy with doxorubicin or carboplatin. Local recurrence occurred in all patients. Patients treated with surgery and chemotherapy presented a longer overall survival and disease-free interval when compared to those that solely received surgical treatment, although no statistical significance was observed ( $\mathrm{p}=0.3360$ and 0.7506 , respectively). Surgery remains as the main option for FISS treatment. Further prospective studies with larger samples are warranted to investigate the benefit of chemotherapy for this neoplasm.
\end{abstract}

Keywords: FISS, Doxorubicin, Carboplatin, surgery

\section{RESUMO}

O Sarcoma de Aplicação Felino (SAF) é uma neoplasia associada a redução na qualidade de vida e sobrevida global. O objetivo deste estudo foi avaliar a eficácia da quimioterapia associada à cirurgia no manejo do SAF. Estudo retrospectivo de 13 pacientes com SAF submetidos à cirurgia isolada ou associada a quimioterapia com carboplatina ou doxorrubicina. Recorrência local ocorreu em todos os pacientes. Pacientes tratados com cirurgia e quimioterapia apresentaram maior sobrevida global e intervalo livre de doença quando comparados àqueles que receberam apenas tratamento cirúrgico, mas não foi observada diferença estatística ( $p=0,3360$ e 0,7506, respectivamente). A cirurgia continua sendo a principal opção para o tratamento do SAF. Estudos prospectivos são necessários para investigação do real benefício da quimioterapia para esta neoplasia.

Palavras-chave: FISS, Doxorubicin, Carboplatin, cirurgia

\section{INTRODUCTION}

Feline injection site-associated sarcoma (FISS) was first described by Hendrick and Goldschmidt (1991), following an increase in the incidence of fibrosarcomas in cats after 1987. The observed increase coincided with the beginning of mandatory administration of anti-rabies vaccine containing adjuvants in the northeast of the United States of America. It was hypothesized that profound and persistent inflammation, secondary to adjuvants or other components of vaccines and drugs, trigger neoplastic transformation of resident fibroblasts, in genetically predisposed cats (Hendrick, et al., 1994).

The real incidence of FISS remains undefined, with reports varying between $0.32 / 10000$ vaccinations (Gobar and Kass, 2002) to $1 / 1000$ injections (Lester et al., 1996; Gobar and Kass, 2002). The presence of a nodule in a site commonly used for subcutaneous and intramuscular injections should alert the veterinary for the possibility of FISS. Presumptive diagnosis can be performed through cytology and definitive diagnosis can be obtained through histopathology (Amorim, 2007).

Recebido em 20 de março de 2016

Aceito em 8 de setembro de 2016

E-mail: silviatrindade@clinicamedvet.com.br 
Even when aggressive treatments are instituted for FISS, metastasis rates can reach $22.5 \%$ (6), while recurrences are found in up to $80 \%$ of cases $(6,7,8)$. Complete tumor excision with clear margins at the initial surgical intervention seems to improve prognosis (Davidson et al., 1997; Hershey et al., 2000). Morrison and Starr (2001) state that there are no satisfactory treatment options and prognosis is poor.

Chemotherapy efficacy for FISS treatment still remains unclear, with variable results in the literature (Ladlow, 2013). Some authors suggest that the combination of surgery with chemotherapy and/or radiotherapy can increase disease-free interval (DFI) and/or overall survival (OS) or add other benefits to quality of life (Barber et al., 2000, Kobayachi et al., 2002; Poirier et al., 2002), while others deny a significant difference when compared to surgical excision as the only treatment (Cronin et al., 1998; Bregazzi et al., 2001; Cohen et al., 2001). Two in vitro studies evidenced a dose dependent sensitivity of some FISS lineages to doxorubicin, mitoxantrone, vincristine and paclitaxel (Williams et al., 2001; Banerji et al., 2002).

The aim of the present study was to compare different treatment protocols including surgery and chemotherapy with doxorubicin and carboplatin through OS and DFI analysis.

\section{MATERIAL AND METHODS}

A retrospective analysis of FISS cases diagnosed between 2001 and 2013 was performed. Samples were obtained from the archives of the Pathology Sector of the Veterinary School and the Laboratory of Comparative Pathology, at the Federal University of Minas Gerais. Clinical data of the selected animals including tumor location and size (considered as the largest diameter observed and defined by macroscopic evaluation following surgical excision), histological diagnosis, treatment protocol, and clinical evolution were obtained through evaluation of clinical records and interviews with the veterinarian and/or owner of the animal. In all cases presumptive diagnosis was obtained by fine needle aspiration followed by cytological analysis and definitive diagnosis was done through hystopathological analysis following surgical excision.
Patients were divided into two groups, according to two different treatment protocols: G1, animals submitted solely to surgical excision; and G2, animals submitted to surgery and chemotherapy. Surgical procedures were extensive in attempt to obtain wide surgical margins. Adjuvant chemotherapy was suggested for all patients. However, some pet owners refused this complementary treatment. Chemotherapy protocols included $1 \mathrm{mg} / \mathrm{kg}$ of doxorubicin or $200 \mathrm{mg} / \mathrm{m}^{2}$ of carboplatin, both administered intravenously for four cycles with a 21-day interval. Doxorubicin was considered the drug of choice. Carboplatin was chosen as the second option in cats presenting azotemia, due to the nephrotoxic potential of doxorubicin in cats, and for excessively aggressive and/or agitated cats, due to the longer infusion time required with doxorubicin.

OS was defined (in days) as the period between surgical excision of tumor and death of the patient due to the disease. Animals that died from unknown causes or causes unrelated to the tumor and animals with loss of follow up were censured. OS was evaluated in univariated analysis. SG curves were derived of KaplanMeier estimative. By log-rank test, values were considered statistically significant when $\mathrm{P}<0.05$.

\section{RESULTS}

Thirteen cats, 7/13 (53.8\%) females and 6/13 $(46.2 \%)$ males, were evaluated. All patients presented nodules in common injection sites, leading to a suspicion of FISS. Regarding tumor location, 6/13 (46.1\%) were located in the thoracic dorsal region, $2 / 13(15.4 \%)$ in the flank, $1 / 13(7.7 \%)$ in the costal region, $2 / 13(15.4 \%)$ in the lumbar region and $2 / 13(15.4 \%)$ in the distal portion of a limb. Tumor size ranged from 2 to 10 centimeters (mean $4.57 \pm 2.82 \mathrm{~cm}$ ). Surgical margins were evaluated in five cases, and considered clear in 1/5 (20\%).

Clinical follow-up was performed for an average period of 544 days (30 - 1975 days). Surgical excision was the only treatment in $5 / 13(38.5 \%)$ and chemotherapy was performed in $8 / 13$ $(61.5 \%)$ cases, 4/13 (30.7\%) animals received doxorubicin and 4/13 (30.7\%) carboplatin. Tumor recurrence was observed in $100 \%$ of the patients. 
Metastasis was observed in $1 / 13(7.7 \%)$ case in which a dorsal primary neoplasm metastasized to the proximal region of the posterior limb of the patient. Two patients presented intense tumoral infiltration (subcutaneous and lymphatic), invalidating a new surgical procedure aiming towards complete excision.
Death related to FISS progression occurred in 9/13 patients $(69.2 \%), 3 / 9 \quad(33.3 \%)$ were euthanized. One patient suffered medullary compression in the lumbar region by the neoplastic mass recurrence. OS was of 450 days for $\mathrm{G} 1$ and 850 days for $\mathrm{G} 2$ ( $\mathrm{p}=0.3360$ ) (Fig. 1), respectively. DFI was of 180 and 383.5 days for G1 and G2 (p=0.7506) (Fig. 2), respectively.

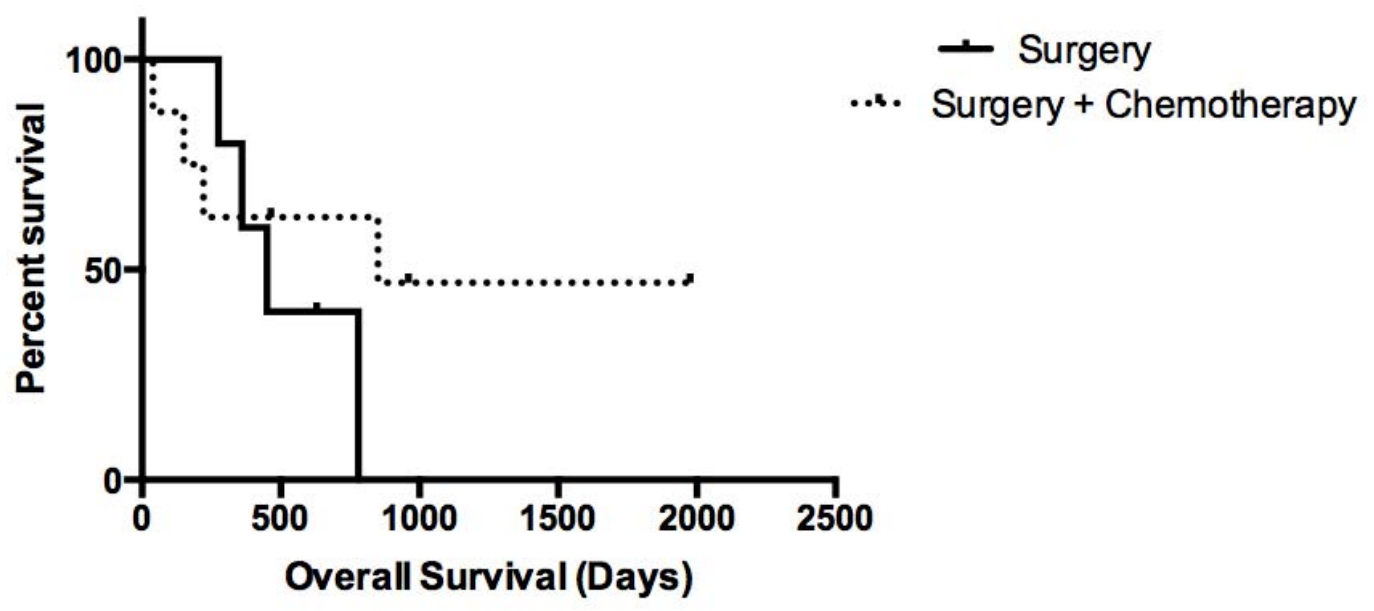

Figure 1. Curves of Overall Survival of 13 patients with Feline Injection Site-Associated Sarcoma according to therapy. Patients submitted to surgical treatment alone, 5 cases (450 days) and conventional surgical excision and chemotherapy, 8 cases ( 850 days $)(p=0.3360)$.

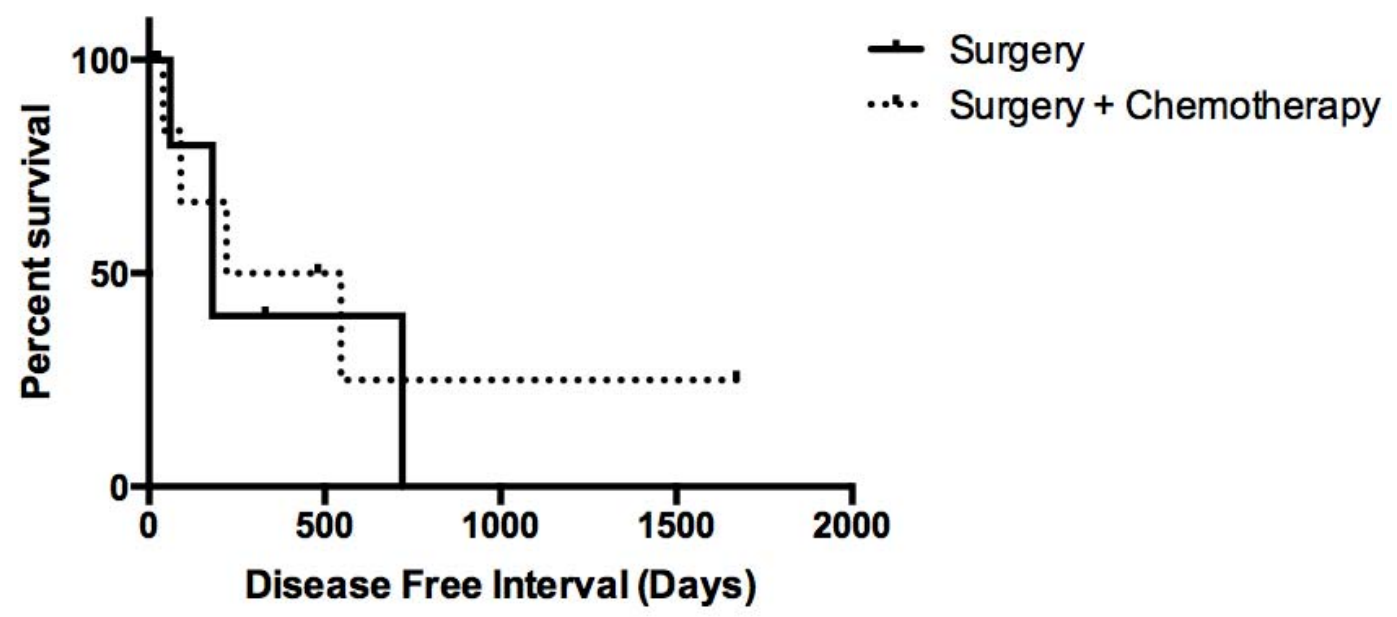

Figure 2. Curves of Free From Disease Interval of 13 patients with Feline Injection Site-Associated Sarcoma according to therapy. Patients submitted to surgical treatment alone, 5 cases (180 days) and conventional surgical excision and chemotherapy, 8 cases (383.5 days) $(p=0.7506) .180$ and 383.5 days for $\mathrm{G} 1$ and $\mathrm{G} 2(\mathrm{p}=0.7506)$ 


\section{Pereira et al.}

\section{DISCUSSION}

In the present study, surgical margins were considered clean in $20 \%$ of evaluated cases. One of the widespread prognostic factors for FISS is complete excision with clean margins of neoplasm at the first surgical procedure, which seems to contribute towards an increase in DFI (Davidson et al., 1997; Hershey et al., 2000) and OS (Davidson et al., 1997), although two recent studies reported an absence of correlation between the status of surgical margins and prognosis (Cohen et al., 2001, Martano et al., 2005). The obtainment of clean surgical margins is considered important for predicting local recurrence of FISS (Kobayachi et al., 2002; Giudice et al., 2010). But there are reports of up to $50 \%$ recurrence rates in neoplasms excised with clear surgical margins (Romanelli et al., 2008; Phelps et al., 2011). This high recurrence rate can be explained by an asymmetrical dissemination of neoplastic cells, hindering accurate margin assessment (Giudice et al., 2010; Ehrhart \& Powers, 2013). Another theory is that the inflammation caused by the surgical treatment can cause a new oncogenic process in genetically predisposed patients, causing recurrence (Ladlow, 2013).

Metastasis was observed in only 1 patient. Metastasis risk probably increases as survival time increases (The..., 2005), and occurs mainly in the lungs, but have been observed in other sites, such as regional lymph nodes, mediastinum, pericardium, liver, bones, pancreas, gut, spleen and eyes (Seguin, 2002). Therefore, it is important to search for regional and distant metastasis in all FISS patients (Ladlow, 2013).

Doxorubicin has been described as the drug of choice for FISS (Poirier et al., 2002). The adverse dose-limiting effect for this chemotherapeutical agent in felines is neutropenia, anorexia, and nephrotoxicity (O'Keefe et al., 1993). Carboplatin is suggested as a chemotherapy agent for FISS, but the efficacy is not completely elucidated (Hauck, 2003; Kisseberth et al., 2008). Although the patients treated with chemotherapy presented a longer median of overall survival when compared to the group treated solely with surgery in the present study, no statistical significance was observed. Poirier et al. (2002) observed and increase in DFI, but not in OS, in patients that were submitted to surgery and chemotherapy with doxorubicin or liposomes encapsulated doxorubicin. Martano et al. (2005) suggests that chemotherapy with doxorubicin only increases surgical possibilities and extends life expectation for animals with inoperable neoplasms. Barber et al. (2000) treated 12 inoperable tumors with a combination of doxorubicin and cyclophosphamide and observed a reduction of up to $50 \%$ in tumor size of six patients. However, the reduction had a short duration and all cats presented progressive disease. In a phase I study that submitted cats with diverse cancers, including FISS, to chemotherapy with carboplatin, Kisseberth et al. (2008) described a partial response of short duration.

\section{CONCLUSIONS}

No statistical significance was found when studying the association of chemotherapy to the surgical treatment of patients with feline injection site-associated sarcoma. Although an important difference in disease free interval and overall survival medians were observed. Therefore, additional prospective studies with larger sample sizes should be performed to enable a better understanding of adjuvant treatments for feline injection site-associated sarcoma.

\section{REFERENCES}

AMORIM, F.V. Sarcomas de locais de injeção. Acta Sci. Vet., v.35, s.221-s223, 2007.

BANERJI, N.; LI, X.; KLAUSNER, J.S.; KAPUR, V. et al. Evaluation of in vitro chemosensitivity of vaccine-associated feline sarcoma cell lines to vincristine and paclitaxel. Am. J. Vet. Res., v.63, p.728-732, 2002.

BARBER, L.G.; SORENMO, K.U.; CRONIN, K.L.; SHOFER, F.S. Combined doxorubicin and cyclophosphamide chemotherapy for nonresectable feline fibrosarcoma. J. Am. Anim. Hosp. Assoc., v.36, p.416-421, 2000.

BREGAZZI, V.S.; LARUE, S.M.; MCNIEL, E.; MACY, D.W. et al. Treatment with a combination of doxorubicin, surgery, and radiation versus surgery and radiation alone for cats with vaccine-associated sarcomas: 25 cases (1995-2000). J. Am. Vet. Med. Assoc., v.218, p.547-550, 2001. 
COHEN, M.; WRIGHT, J.C.; BRAWNER, W.R.; SMITH, A.N. et al. Use of a surgery and electron beam irradiation, with or without chemotherapy, for treatment of vaccine-associated sarcomas in cats: 78 cases (1996-2000). J. Am. Vet. Med. Assoc., v.219, p.1582-1589, 2001.

CRONIN, K.; PAGE, R.L.; SPODNICK, G.; DODGE, $\mathrm{R}$. et al. Radiation therapy and surgery for fibrosarcoma in 33 Cats. Vet. Radiol. Ultrasound, v.39, p.51-56, 1998.

DAVIDSON, E.B.; GREGORY, C.R.; KASS, P.H. et al. Surgical excision of soft tissue fibrosarcomas in cats. Vet. Surg.,v.26, p.265-269, 1997.

EHRHART, E.J.; POWERS, B.E. The pathology of neoplasia. In: Withrow, S.J.; VAIL, D.M. Withrow \& McEwen's small animal oncology. 5.ed. Missouri: Elsevier, 2013. p.51-67.

GIUDICE, C.; STEFANELLO, D.; SALA, M.; CANTATORE, M. et al: Feline injection-site sarcoma: recurrence, tumour grading and surgical margin status evaluated using the three-dimensional histological technique. Vet. J., v.186, p.84 -88, 2010.

GOBAR, G.M.; KASS, P.H. World Wide Web-Based Survey of vaccination practices postvaccination reactions, and vaccine-site associated sarcomas in cats. J. Am. Vet. Med. Assoc., v.220, p.1477-1482, 2002.

HAUCK, M. Feline injection site sarcomas. Vet. Clin. N. Am. Small Anim. Pract., v.33, p.553-571, 2003.

HENDRICK, M.J.; GOLDSCHIMIDT, M.H. Do injection site reactions induce fibrosarcomas in cats? (letter). J. Am. Vet. Med. Assoc., v.199, p.968, 1991.

HENDRICK, M.J.; SHOFER, F.S.; GOLDSCHMIDT, M.H.; HAVILAND, J.C. et al. Comparison of fibrosarcomas that developed at vaccination sites and at nonvaccination sites in cats: 239 cases (1991-1992). J. Am. Vet. Med. Assoc., v.205, p.1425-1429, 1994.

HERSHEY, A.E.; SONREMO, K.U.; HENDRICK, M.J.; SHOFER, F.S. et al. Prognosis for presumed feline vaccine-associated sarcoma after excision: 61 cases (1986-1996). J. Am. Vet. Med. Assoc., v.216, p.58-61, 2000 .

KOBAYACHI, T.; HAUCK, M.L.; DODGE, R.; PAGE, R.L. et al. Preoperative radiotherapy for vaccine associated sarcoma in 92 cats. Vet. Radiol. Ultrasound, v.43, p.473-479, 2002.

KISSERBERTH, W.C.; VAIL, D.M.; YAISSLE, J.; JEGLUM, K.A. et al. Phase I clinical evolution of carboplatin in tumor-bearing cats: a veterinary comparative oncology group study. J. Vet. Int. Med., v.22, p.83-88, 2008.
LADLOW, J. Injection-Site associated sarcoma in the cat: treatment recommendations and results to date. $J$. Feline Med. Surg., v.15, p.409-418, 2013.

LESTER, S.; CLEMELT, T.; BURT, A. et al. Vaccine site-associated sarcomas in cats: clinical experience and a laboratory review (1982-1993). J. Am. Vet. Med. Assoc., v.32, p.91-95, 1996.

MARTANO, M.; MORELlO, E.; UGHETTO, M.; IUSSICH, S. et al. Surgery alone versus surgery and doxorubicin for the treatment of feline injection-site sarcomas: a report on 69 cases. Vet. J., v.170, p.84-90, 2005.

MORISSON, W.B.; STARR, R.M. Vaccineassociated feline sarcomas. J. Am. Vet. Med. Assoc., v.218, p.697-702, 2001.

O'KEEFE, D.A.; SISSON, D.D.; GELBERG, H.B.; SCHAEFFER, D.J. et al. Systemic toxicity associated with doxorubicin administration in cats. J. Vet. Inter. Med., v.7, p.309-317, 1993.

PHELPS, H.A.; KUNTZ, C.A.; MILNER, R.J.; POWERS, B.E. et al. Radical excision with fivecentimeter margins for treatment of feline injectionsite sarcomas: 91 cases (1998-2002). J. Vet. Am. Med. Assoc., v.239, p.97-106, 2011.

POIRIER, V.J.; THAMM, D.H.; KURZMAN, I.D.; JEGLUM, K.A. et al. Liposome-encapsulated doxorubicin (Doxil ${ }^{\circledR}$ ) e doxorubicin in treatment of vaccine-associated sarcoma in cats. J. Am. Vet. Med. Assoc., v.16, p.726-731, 2002.

ROMANELLI, G.; MARCONATO, L.; OLIVERO, D.; MASSARI, F. et al. Analysis of prognostic factors associated with injection-site sarcomas in cats: 57 cases (2001-2007). J. Vet. Am. Med. Assoc., v.232, p.1193-1199, 2008.

SEGUIN, B. Injection sarcoma in cats. Clin. Tech. Small Anim. Pract., v.17, p.168-173, 2002.

THE current understanding and management of vaccine-associated sarcomas in cats. J. Am. Vet. Med. Assoc., v.213, p.1428-1429, 2005. (VACCINEASSOCIATED FELINE SARCOMA TASK FORCE).

WILLIAMS, L.E.; BANERJI, N.; KLAUSNER, J.S.; KAPUR, V. et al. Establishment of two vaccineassociated feline sarcoma cell lines and determination of in vitro chemosensitivity to doxorubicin and mitoxantrone. Am. J. Vet. Res., v.62, p.1354-1357, 2001. 